\title{
SURVEY AND POPULATION DENSITY OF SOME INSECT AND MITE PESTS INFESTING CHICORY PLANT (CICHORIUM INTYBUS L.) IN GIZA GOVERNORATE, EGYPT
}

\author{
SOBHY H. M. ${ }^{1}$, M. M. H. EL - BOLOK ${ }^{2}$, \\ M. F. A. H. HEGAB. ${ }^{3}$ AND N.W.T. BEBAWI. ${ }^{3}$
}

\author{
1. Institute of African Research and Studies, Cairo Univ. \\ 2. Faculty of Agric., Cairo Univ. \\ 3. Plant protection Research institute, ARC, Dokki, Giza.
}

(Manuscript received 10 February 2015)

\begin{abstract}
$\mathrm{T}$ he present investigation was carried out at the experimental farm of Agricultural Research Centre, Giza Governorate, Egypt throughout two successive seasons (2010 and 2011) on chicory plants. Obtained results clearly indicated the following: 1) Twenty seven species of insects and mites were surveyed on Chicory plants during the two successive growing seasons. 2) Eight insects and mites considered important pests. 3) The spider mite Tetranychus urticae Koch proved to be the most abundant species during the two growing seasons showing the highest population density general mean recording 26. 47, 15.60 movable stages/sample in the two seasons, respectively. The lowest density was obtained with the phytophagous mite Bryobia sp. 4) Six insect pests their population density general means were intermediate, these insects were the aphid Uroleucon ambrosiae (Thomas), the white fly B. tabaci (Genn.), Thrips tabaci Lind., the potato leaf hopper Empoasca decipiens (Paoli), the sugar cane mealy bug Saccharicoccus sacchari (Cockerell) and the sugar beet fly Pegomyia mixta (Will) during two seasons.
\end{abstract}

\section{INTRODUCTION}

Chicory plant is one of the most important economic grazing medical and industrial crops, spread now in most of European, North and South of America, India, China and South Africa countries.

It is member of family Compositae (Asteraceae) with the scientific name Cichorium intybus and common names, Witloof Chicory, Red leaf Chicory, Salad Chicory, Chicoriae, Belgian endive and Blue sailors.

The international cultivated area of $C$. intybus lasted to (23058 ha) and producing (902240 tones) of roots during (2011) FAO Statistic Division 2013.

It is considered as a forage crop for farm animals (Sitzia et al., 2006 in Italy, Chen et al., 2005 in USA and Golding et al., 2011 in North Newzealand). 
Many records were obtained with the important insects and mites damaging Chicory plants in the fields. Aphids: (Stoetzel and Russell, 1991 in USA and Kos et al., 2012 in Slovenia),Whitefly: (Zanic et al., 2001 in Croatia), Thrips: (Smith, et al., 2011 in Western New York), Jassids: (Bogoutdinov, 2002 in Russian), Leaf miners: (Dempewolf, 2004 in Australia and Huangjun et al., 2011), Lepidopterous: (Artigala 1936 in South of France, Proft, 2000 in Belgium, Sethi et al., 2006 in southern Florida and Midgley et al., 2008 in South Africa),The green stink bug: (Khalaphallah et al., 2005 in Egypt), Spider mite: (Farshad et al., 2013 in Iran).

The present study aimed to through the light on the insect and mite pests infesting chicory plant under Egyptian agricultural conditions for preparing the data which will be beneficial during the near future in Egypt.

The scope of this study aimed to:-

1- Survey and identifying the insect and mite pests infesting Chicory plants under field conditions during two seasons, 2010 and 2011.

2- Evaluating the population density of the important insect and mite pests on Chicory plants during 2010 and 2011seasons at Giza Gov. Egypt.

\section{MATERIALS AND METHODS}

The following technical methods were followed:-

1-Survey of insect and mite pests infesting Chicory plants (Cichorium intybus L.) during 2010 and 2011 seasons.

Seeds of Chicory plants were sown in the nursery inside a plastic green house on the $1^{\text {st }}$ of November 2009, then seedlings were transplanted on 15/12/2009 in an area of about $1 / 4$ Fadden ( 6 kirats).

The study was conducted at the farm of Agricultural Research Centre at Giza Governorate. Sampling started on the $2^{\text {nd }}$ of January 2010 and 18/11/2011, two weeks after transplanting for the two tested seasons, respectively.

Plants in the field received all the recommended agricultural practices except using any of the pesticides.

The largest size of mature and immature stages of the surveyed and collected insects from leaves and plant parts were picked and preserved in bottles contain $70 \%$ alcohol, also the surveyed small insect and mites were mounted in microscope slides. The identification of samples was carried out in Survey and Classification Dep., Plant Protection Research Institute, Giza, Dokki, Egypt.

In some cases the unknown (larvae or nymphs) were reared under laboratory conditions for obtaining the adult to be identified, the sample stages, period of occurring and frequency of the species numbers were recorded.

Surveyed species were listed and arranged according to their taxonomical position in Table 1. 


\section{2-Population density of the important insect and mite pests on Chicory plants during 2010 and 2011 seasons.}

From the above experimental area, samples of Chicory leaves were collected randomly from 3 replicates, each of them 3 lines of $6 \times 0.5$ meters, 30 randomly leaves were picked (10 leaves/sample), then kept in paper bags and transferred to laboratory for counting the insect and mite pests by the aid of Stereomicroscope starting from 2/1/2010 till the end of the growing season at 29/5/2010 and repeated at $18 / 11 / 2010$ in the next season to $12 / 5 / 2011$.

\section{RESULTS AND DISCUSSION}

\section{Survey:}

The surveyed insect and mite pests infested C.intybus in the field at Giza Governorate during 2010 and 2011 seasons were recorded in Table 1.

Results revealed the presence of 27 species belonging to 17 families (Muscidae, Aleyrodidae, Aphidae, Jassidae, Lygayeidae, Pentatomidae, Pseudococcidae, Lycaenidae, Nymphalidae, Pieridae, Perophoridae, Noctuidae, Acrididae, Thripidae,Tetranychidae, Eriophidae, Pymotidae) from 6 orders (Diptera, Hemiptera, Lepidoptera, Orthoptera, Thysanoptera, Acarina).These species are listed systematically in Table (1). The pests including 21 insects and 6 mites, the found stage, frequency, period of occurrence of every species are shown in the same table.

\section{Population density:}

\subsection{The phytophagous mite, Tetranychus urticae Koch:}

Results in Table 2 demonstrated that the phytophagous mite $T$. urticae Koch proved to be the most abundant species on chicory plants, movable stages and eggs of that mites during the two tested growing seasons 2010 and 2011, showing the highest general mean number / (10 leaves) of 26.47, 15.60 movable stages during the $1^{\text {st }}$ and $2^{\text {nd }}$ tested seasons without significant difference between the two seasons and recorded 23.15, 23.13 eggs / (10 leaves) during the tested seasons and also non significant.

These results are in line with those obtained by Farshad, et al., (2013) in Iran, determine the abundance phytophagous mite species recording 23 species belonging to 18 genera from 15 different families of the Sub class Acari were collected and identified. Two spotted spider mite ( $T$. urticae) was the most widely distributed with high populations in certain locations. No considerable damage was noticed on the host plants because the predator mites are effective in reduction of its population.

In contrary the lowest density was appeared with the phytophagous mite Bryobia sp. infestation recording a general mean /sample zero and 0.23 mites/ sample during the tested seasons, respectively, Table (2). 
Chicory plant was infested with another 6 insect pests during the two tested seasons recording the following general means of their density:

2.2. The aphid, Uroleucon ambrosiae (Thomas): recording 6.42 and 5.33 aphids/10 leaves (not sign.) between the two tested seasons.

These results are in line with those obtained by El- Roby (2009) recorded small numbers of the green peach aphid, Myzus persicae Sulzer ranged between 2.3- 0.3 individuals / 10 leaves of Jerusalem artichoke (Asteraceae) with a general mean of 1.4 individuals/sample during the period from $19 / 4 / 2002$ to 29/10/2002. Aphids infestation was higher during 2003 season comparing with the first experimental season with general mean lasted to 2.7 insects/10 leaves. Nuessly and Webb (2010) recorded several species of aphids affect Lettuce (Asteraceae), including green peach aphid, M. persica, potato aphid, Macrosiphum euphorbiae and the aphid, Uroleucon pseudambrosiae. These species of aphids are most economically damaging in Florida. Huangjun et al., (2011) in southern Florida, recorded that potato aphid, M. euphorbiae was the predominant species of aphids on Lettuce and was noted to be present from the beginning of Dec. 2010 to the end of the experiments (Jan. 2011). The population density was low in Dec. 2010 but high in Jan. 2011. Large numbers of aphid were found to stay together on the backsides of leaves in Jan.2011.

2.3. The white fly, Bemisia tabaci (Genn.) nymphs: infested Chicory plants with general means 1.04 and 2.64 nymphs / (10 leaves) during the two tested seasons, respectively, (high sign.)

These results are in line with those obtained by Zanic et al., (2001) in Croatia, reported that the presence of the tobacco white fly, B. tabaci on C.intybus plants in gardens and private plots from the period of July to October. Nadeem, (2004) at Giza, Egypt, recorded that $B$. tabaci began to attack Globe artichoke (Asteraceae) in the first week of October (1995) by 4.3 individuals/10 leaves. Then insect population decreased to reach its minimum numbers during January, February and March. El-Roby (2009) at El- Kanater El -Khayria, record that B.tabaci began to attack Jerusalem artichoke plant leaves by few numbers of nymphs (6nymphs/10leaves) at the end of April (2002), lasting to its highest number 10.8 nymphs at the end of June (2002, then started a decreasing at 9/7/2002 lasting to the lowest population 4.3 nymphs/10 leaves at the end of the growing season recording a general mean average, 13.6 nymphs during the growing 2002season.

2.4.The thrips, Thrips tabaci Lind.: recorded general means of 7.33 and 1.13 insects/ sample during 2010 and 2011 seasons, respectively, Table (2),(very high sign.).

These results are in line with those obtained by Nadeem, (2004) at Giza, Egypt, whereas that the population of Thrips tabaci on Globe artichoke began its appearance by a few individuals $1 / 10$ leaves on the $14^{\text {th }}$ of October (1995) while Smith et al., 
(2011) in western New York, found that adults of T. tabaci were observed on Chicory plants on 9 June, 26 September 2008 and on 15 June, 10 August 2009.

2.5. The leaf hopper, Empoasca decipiens Paoli: attacked Chicory plants by general means of 1.13 insects and zero / 10 leaves, respectively.

These results are in line with those obtained by Nadeem (2004) at Giza , Egypt, whereas that the infestation with Empoasca decipiens on Globe artichoke at Giza started with 8 individuals /10 leaves on the $7^{\text {th }}$ of October (1995), then increased gradually through October reaching to 21 individuals $/ 10$ leaves on the $4^{\text {th }}$ of Nov.1995, then decreased during Nov., Dec. and Jan. recording the lowest number 1 individuals /leaves, then increased again to reach a mean number of 6 individuals / 10 leaves by the end of the season in March. El-Roby (2009) recorded few numbers of $E$. decipiens appeared on seedling of Jerusalem artichoke till the end of the growing season at 29/7 and 19/9/2002.

2.6. The sugar cane mealy bug, Saccharicoccus sacchari (Cockerell) nymphs : recorded on Chicory plants by 11.95 general mean differed very high significant than 6 . 35 nymphs /10 leaves during the two tested seasons, respectively.

2.7. The sugar beet fly, Pegomyia mixta (Will): larvae recorded on Chicory plants by 0.17 , zero and $P$. mixta eggs recorded 0.25 , and zero / sample during the two tested seasons 2010 and 2011, respectively. Table (2).

These results are in line with those obtained by Nadeem (2004) at Giza, Egypt, said that the numbers of both mines and larvae of Agromyza apfelbecki Strobl. on Globe artichoke were higher in (October \& November) in the $1^{\text {st }}$ season (1995) than in the other months of this season. The highest numbers of larvae 74.8 and 57.2 / 10 leaves were recorded on the $28^{\text {th }}$ of October and the $11^{\text {th }}$ of November 1995, respectively. El-Khouly et al., (2006) at Kafr El-sheikh, Egypt, this study revealed that reliable occurrence of $P$. mixta individuals on Sugar beet plants occurred in Nov. 2004 and 2005 was gradually increased forming distinct peak in March 2005 as well as 2006. Huangjun et al., (2011) in southern Florida reported that mines caused by serpentine leaf miner Liriomyza trifolii (Burgess) in leaves of Lettuce were first observed in the field on the $16^{\text {th }}$ of Nov. 2010 There was only one mine on 'Raleigh' plants with an average 0.1 mine /plant on the $18^{\text {th }}$ of Nov.The mine increased to 3 mines/ plants on 9 Dec. 2010 and had little change from 9 to 16 Dec. 2010.

According to the above mentioned results, simply we can observe that the infestation density with the nymphs of $T$. tabaci was higher significantly in the first season than the second one, while the tetranychid mite T. urticae infested Chicory plants by a very close general mean of the population density through the two tested seasons. The infestation density with the ambrosia aphid U. ambrosiae, the leaf hopper E. decipiens, the stink sugar cane mealy bug nymphs $S$. sacchari and the immature 
stages of the sugar beet leaf fly $P$. mixta was higher during the first tested season than in the second one. Only the white fly $B$. tabaci infestation density was higher with high significancy in the second season than the first one. Table 2.

Table 1. Checklist of surveyed insect, mite pests of Chicory plant (Cichorium intybus L.) in Giza Governorate during 2010 and 2011 seasons.

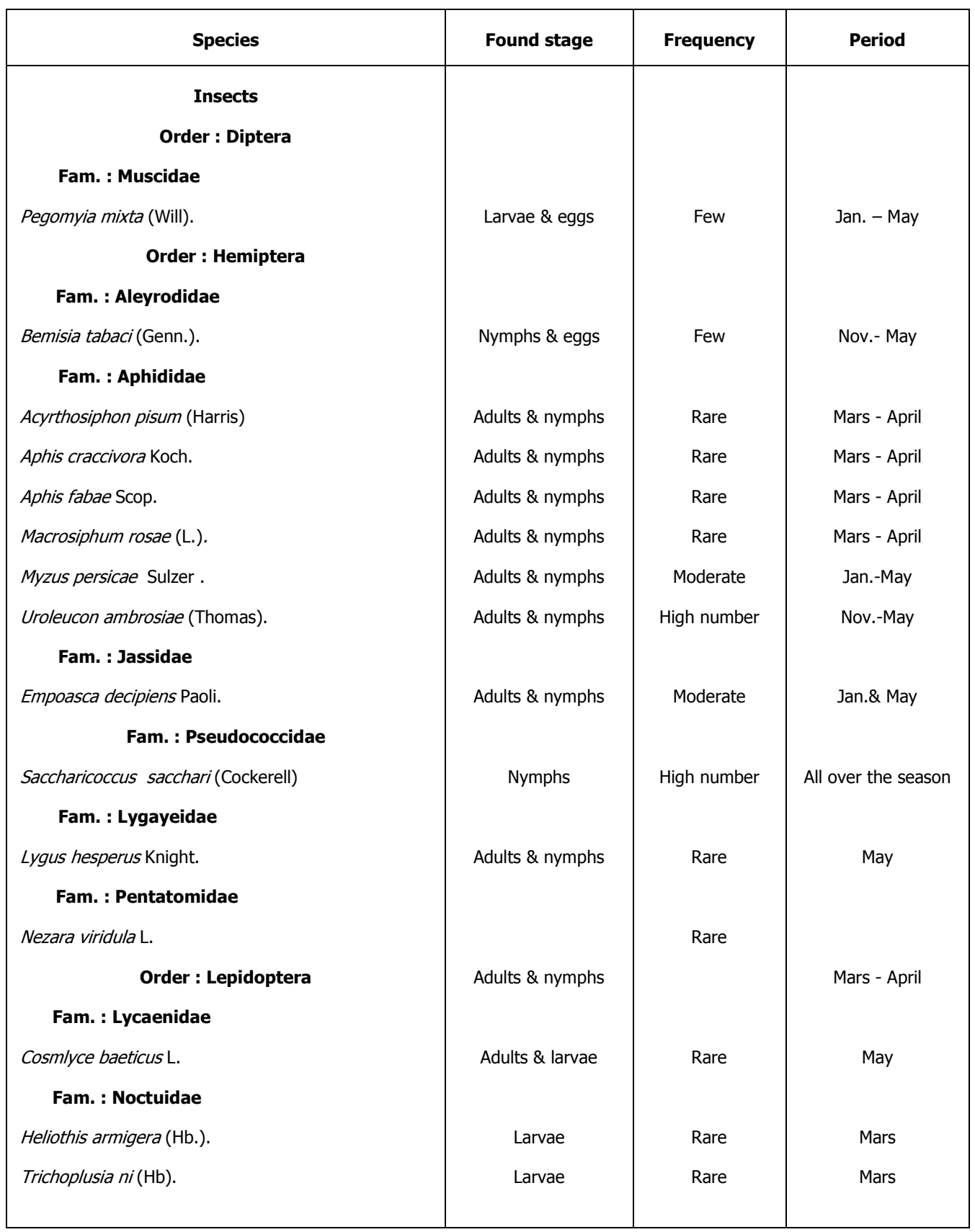


Table 1. Continued

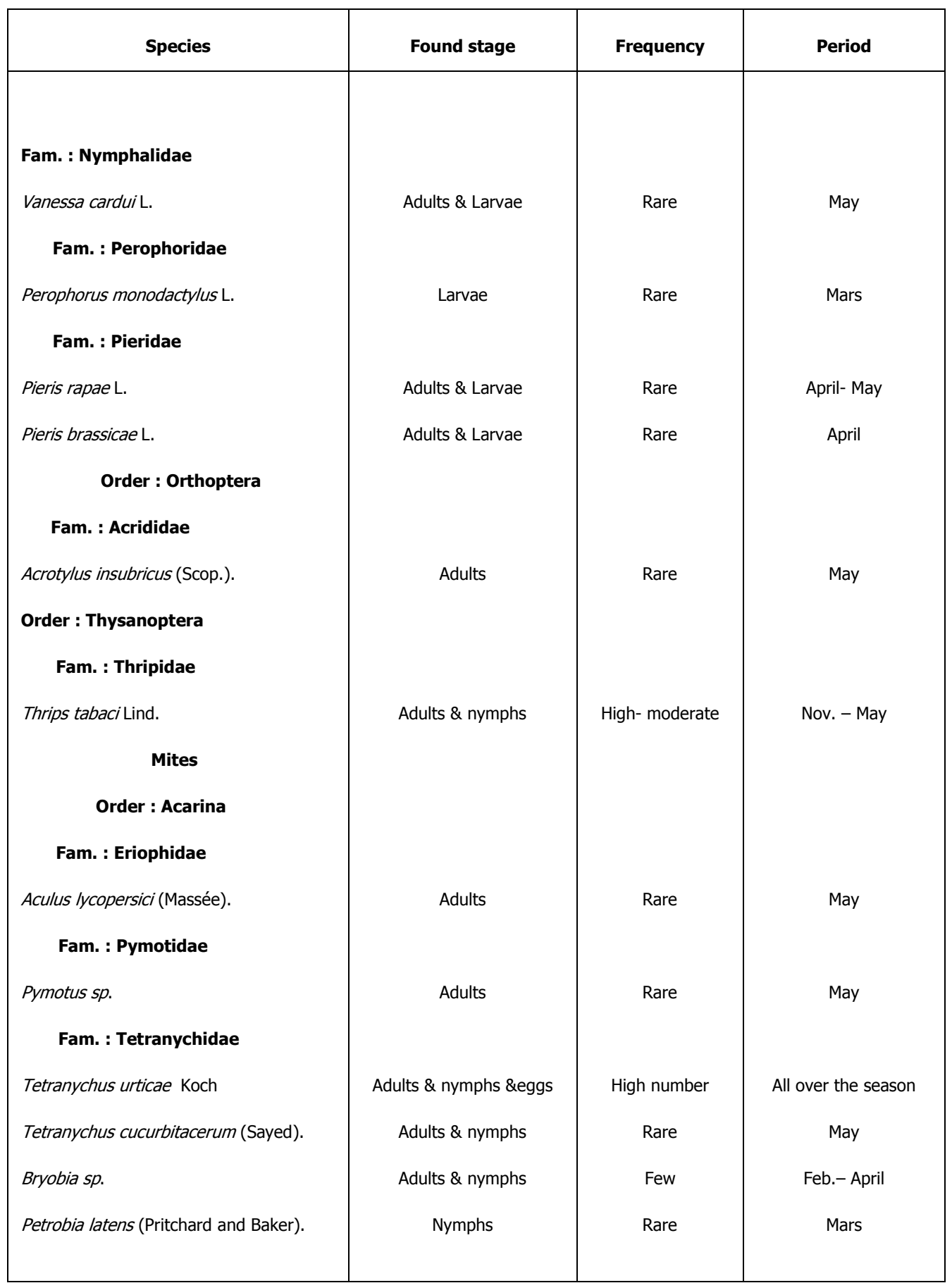


Table 2. General mean number of insect and mite pests infesting Chicory plants during 2010 and 2010 ,2011 seasons at Giza Governorate, Egypt.

\begin{tabular}{|l|c|c|c|}
\hline \multicolumn{1}{|c|}{ Species } & First season & $\begin{array}{c}\text { Second } \\
\text { season }\end{array}$ & Significancy \\
\hline Uroleucon ambrosiae & 6.42 & 5.33 & n.s. \\
\hline Bemisia tabaci (nymphs) & 1.04 & 2.64 & $* *$ \\
\hline Thrips tabaci & 7.33 & 1.13 & $* * *$ \\
\hline Empoasca decipiens & 1.13 & 0 & - \\
\hline Saccharicoccus sacchari (nymps) & 11.95 & 6.35 & - \\
\hline Pegomyia mixta (larvae) & 0.17 & 0 & n.s. \\
\hline Pegomyia mixta (eggs) & 0.25 & 0 & - \\
\hline Tetranychus urticae \\
(m. stages)
\end{tabular}




\section{REFERENCES}

1. Artigala, J. 1936. Quelques enemies des artichausts. Rev. Maroc. Fruits Prim. Afr., 68(6): 277-278.

2. Bogoutdinov, D.Z. 2002. Characteristics of the circulation of the Solanaceae stolbur pathogen in the northern parts of its range. Russian Agric. Sci. 12:1415.

3. Chen, Y. C., Nakthong, C., and Chen, T.C. 2005. Effects of chicory fructans on egg cholesterol in commercial laying hen. Inter. J. Poul. Sci., 4(2): 109-114.

4. Dempewolf, M. 2004. Arthropods of economic importance Agromyzidae of the world. World Biodiversity Database (CD.ROM). University Amsterdam, Amsterdam.

5. El- Khouly, M.I. 2006. Population fluctuations of the beet fly, Pegomyia mixta (Will) and the tortoise beetle, Cassida vitata Vill in relation to certain associated natural enemies in sugar beet Fluids at Kafr El - Sheikh Governorate, Egypt. Egypt. J. Biol. Pest control, 16 (1/2): 25- 28.

6. El - Roby, A.M.M.S. 2009. Biological and ecological studies on the main insect pests infesting Jerusalem artichoke (Helianthus tuberosus L.) in Egypt. Ph. D .Thesis of Environmental Science, Institute of Environmental Studies and Research. Ain Shams University.

7. Farshad M. and Mohammad k. 2013. Mites associated with some medicinal plant (Asteraceae) in Hamedan Iran. J. Crop Prot. 2(2): 209-218.

8. Golding, K. P., Wilson, E.D., Kemp, P.D., Pain, S. J., Kenyon, P. R., Morris, S.T. and Hulton, P.G. 2011. Mixed herb and legume pasture improve the growth of lambs post - weaning. Animal Production Sci., 51(8):717-723.

9. Huangjun Lu, Alan L. Wright and David Sui. 2011. Response of lettuce cultivars to insect pests in southern Florida. Hort Technol., 21 (6): 773- 778.

10. Kos, K., Petrovic - Obradovic, O., Zikic, V., Petrovic, A., Trdan, S. and Tomanovic, Z. 2012. Review of interaction between host plants, aphid, primary parasitoids and hyperparasitoids in vegetable and cereal ecosystems in Slovenia. J. Entomol. Res. Soc., 14(3):67-78.

11. Khalafallah, E.M.E., Shenishen, Z., El-Hawary, I.S. and Khattab, M.A. 2005.The host range and overwintering sites of Nezara viridula L. under Kafr El- Sheikh conditions. Egypt. J. Agric. Res., 83(1):79- 85. 
12. Midgley, J.M. , Hill, M.P. , and Villet, M.H. 2008. Baited traps may be an alternative to conventional pesticides in integrated crop management of Chicory (Compositae) in South Africa. J. Econ. Entomol. 10 (1): 99-106.

13. Nadeem, M.M.A. 2004. Ecological and biological studies on some insect pests infesting globe artichoke plant. M.Sc Thesis, Fac. Agric. Al- Azhar Univ.

14. Nuessly, G. and Webb, S.E. 2010. Insect management for leafy vegetables. Univ. of Florida, Inst. Food Agr. Sci. Ext.ENY-475.

15. Proft , M . de 2000. Pest of chicory. Betteravier Bruxelles, 35 (363): 13.

16. Sethi, A., McAuslane, H.J., Nagata, R.T., Nuessly, G.S. 2006. Host plant resistance in romaine lettuce affects feeding behavior and biology of Trichoplusia ni and Spodoptera exigwa (Lepidoptera : Noctuidae). J. Econ. Entomol., 99:2156-2163.

17. Sitzia, M., Ligios, S. and Fois, N. 2006. Sulla and chicory production and quality under sheep grazing management. Proceeding 21st General Meeting European Grassland Federation, Badajoz, Spain, 448-450.

18. Smith, E.A., Ditommaso, A., Fuchs, M., Shelton, A.M. and Nault, B.A. 2011. Weed hosts for onion thrips (Thysanoptera : Thripidae) and their potential role in the epidemiology of Iris yellow spot virus in an onion ecosystem Enviro. Entomol. 40(2): 194-203.

19. Stoetzel, M.B. and Russell, L.M. 1991. Aphis intybii, a pest of Chicory Intercepted at United States ports of entry (Homoptera : Aphididae). Entomol. Generalis, 16(1): 147-155.

20. Zanic, K., Kacic, S. and Katalinic, M. 2001. Tobacco whitefly, Bemisia tabaci Gennadius, 1889), (Homoptera : Alleyrodidae) in Croatia. Entomol. Croatia, 5(1/2): 51-53 
حصر وكثافة التعداد للأفات الحشرية والأكاروسية الهامة التى تصيب نبات

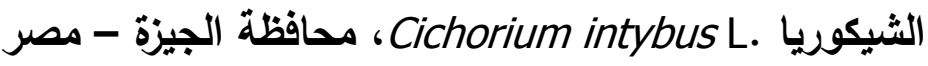

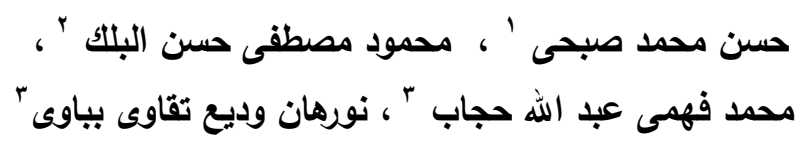

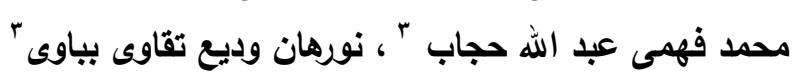

$$
\begin{aligned}
& \text { ا ـ ـ معة البحوث والدراسات الأفريقية } \\
& \text { r r بلية الزراعة جامعة القاهنة } \\
& \text { r. معرد بحوث وقاية النباتات - مركز البحوث الزراعية - الدقى - الجيزة }
\end{aligned}
$$

أجرى هذا البحث بمزرعة مركز البحوث الزراعية بمحافظة الجيزة خلا عامين متتاليين

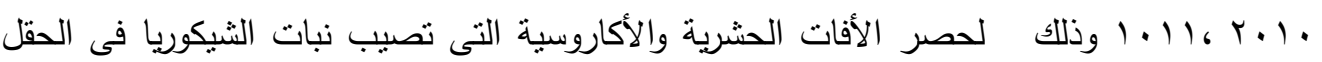

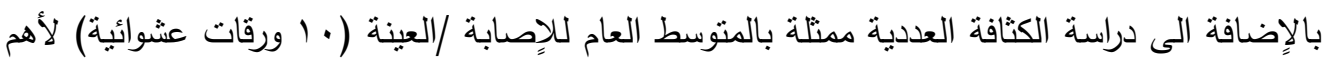
الحشرات والأكاروسات التى تصيب المجموع الخضرى. ويمكن تلخيص النتائج كالتالى:-

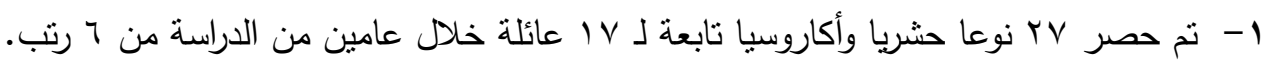

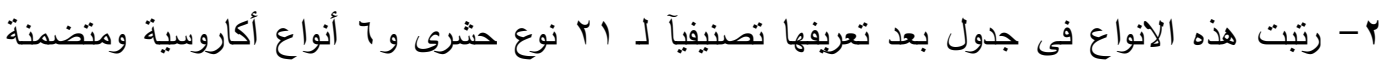
الأطوار وتواجدها وفتزة التواجد.

ب- لقد دلت نتائج دراسة تعداد أهم ثمانية أفات تصيب نباتات الثيكوريا أن العنكبوت الأحمر هو أكثر

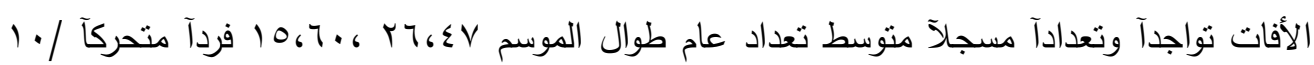

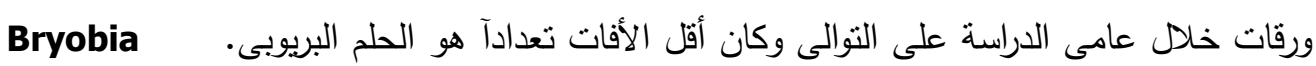
؛ - بينما سجلت 7 أفات حشرية متوسطات عامة خلال عامى الدراسة وكانت وسطآ بين تعداد العنكبوت

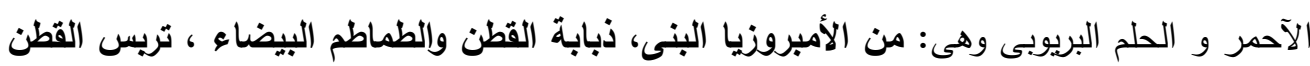

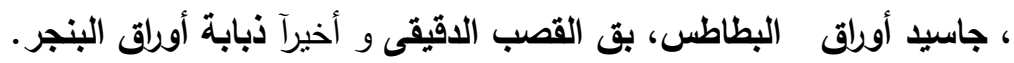

